\title{
Ocular Adnexal Mucosa-Associated Lymphoid Tissue Lymphoma
}

National Cancer Institute

\section{Source}

National Cancer Institute. Ocular Adnexal Mucosa-Associated Lymphoid Tissue

Lymphoma. NCI Thesaurus. Code C35689.

An extranodal marginal zone lymphoma of mucosa-associated lymphoid tissue that arises from the ocular adnexa. It is the most common type of primary ocular adnexal lymphoma. 